\title{
THE ENGLISH THEATRE ORCHESTRA: ITS RISE AND EARLY CHARACTERISTICS
}

\author{
By W. J. LAWRENCE
}

$\mathrm{N}^{\circ}$

0 longevous word incorporated from a dead language into a living one has been tortured into so many meanings as the word orchestra. It is the very Wandering Jew of vocables. But the great diversity of interpretations it has borne throughout its remarkably long career affords no warrant to the musico-dramatic historian, with any pretensions toward scientific exactitude, for its slipshod use. Instances of the employment of the term in its current meaning in a highly anachronistic way come readily to mind. There is, for example, a sentence in Dr. George Brandes' William Shakespeare, which not only errs in this respect but abounds in inaccuracy of statement:

At the Globe theatre the orchestra was placed in the upper proscenium box on the right; it was the largest in London, consisting of 10 performers, all distinguished in their several lines, playing lutes, oboes, trumpets and drums.

One might just as well argue that when The Castle of Perseverance was performed in the open, circa 1470, the orchestra was already in existence, basing one's statement on the fact that when Humanum Genus was foolish enough to make choice of the Bad Angel for his guardian, "the mynstrells," according to an old stage direction, were expected to "pipe up" in order to draw attention to the grave blunder he had committed. The truth is -and it is quite time the point should be fully demonstratedthat, while music and the drama have always been closely associated and no primitive modern playhouse but had its musicians, ${ }^{1}$ the theatre orchestra, as we know it, is purely the child of Opera. The period of its origin can be closely approximated by the fact that its designation applied in the beginning to a particular locality, and not, as was afterwards brought about by a natural process of metonymy, to the musicians who occupied that locality.

\footnotetext{
It abould be recallod that long before specialisation of function set in many of the pleyers were cound musiciens and provided their ows eccompaniments. Bven down to the dose of the ceventeenth centary the Italinn comedians of Part vere expert luteniste.
} 
In the original Greek the word orchestra meant "the dancingplace" and signified that space of lowest level between actors and audience where the chorus performed its evolutions to a musical accompaniment.

Musico-dramatic historians, having failed to grasp the importance of the event, have made no attempt to determine the moment in the early days of Opera when the musicians were removed from their obstructive position behind the scenes and placed in an enclosure along the parapet of the stage. When we come to consider that practical instrumentation only became possible with this change, that with the establishment of the orchestra there was glimmering recognition of it as a separate, if co-operative, entity-something which of itself added to the sum total of artificially aroused emotions-this neglect seems all the more reprehensible. So much stress has been laid upon Monteverdi's innovative genius as the Father of Instrumentation that the way has insidiously been paved for us to draw the inference that he was the first to place the musicians in their now familiar position. But that assumption remains unwarranted by the evidence. When we read that in Arianna, in 1608, Monteverdi employed the large number of 36 instruments, we fail to see how so considerable a body of musicians could have been grouped together behind the scenes, and our imagination at once establishes the first orchestra. This reasoning is fallacious. It overlooks the fact that in Monteverdi's early operas the necessity for arraying the players in close order was precluded. Certain instruments were reserved for the accompaniment of certain voices, and it was only in an occasional chorus that all the instruments were employed. Hence the musicians could have been readily accommodated on scaffolds erected behind the side-scenes, a system which, as we shall see presently, was then commonly practised.

It is requisite also to recognize that in the early days of Opera, before music-lovers became surfeited with the magic and marvels of classic mythology and began to clamor for historical themes, the persistence of a not ungrateful stage convention, which had been a prime characteristic of the intermedi, obviated for long the necessity of an orchestra. In the intermedi of the latter half of the sixteenth century every scene was self-contained and presented its own individual music, the musicians being virtually figurantes and appropriately dressed in harmony with the action. As often as not they were seen playing on clouds during the descent to earth of some divinity. Moreover, as is to be noted in the intermedi of La Cofanaria, given at Florence in 
1565, singers and dancers occasionally played their own accompaniments.

If, then, there were no pressing problems of instrumentation in Monteverdi's day whose solution imperatively demanded the establishment of the orchestra, to what inspiring cause are we to attribute its origin? Some one has argued that the site was chosen because it was equally good for hearing in all parts and because there the music is rarely overpowering to the singer, who throws his voice over it. But the Italian musicians of the early sevententh century, like the English, had a predilection for an elevated position, and nothing short of sheer expediency could have overcome their distaste for being sunk in the depths. My own opinion is that the principle of the orchestra was first established in 1637 with the opening of the Teatro di San Cassiano, the first public Opera-house, in Venice. Questions of ways and means would have necessitated this arrangement. Baroque opera was nothing if not spectacular: it demanded a considerable variety of readily changeable scenery and much elaborate stage mechanism. Under these conditions, the presence of numerous musicians and their impedimenta in the regions behind, however suffered in the earlier days of private representation, was "most tolerable and not to be endured."

One reason why I have arrived at this conclusion is that in the Practica di fabricar Scene a Machine ne' Teatri of Nicola Sabbatini, a curious manual of instruction issued at Ravenna in 1638 , and dealing only with the construction of temporary theatres for private performances, no clue to the existence of the orchestra occurs in the section on "Come si debbano accomodare i Musici," (Lib. I, Cap. 36) or elsewhere throughout the book. Sabbatini knows only of two methods of accommodating the musicians. In the first he places them in the auditorium in elevated boxes adorned with balustrades and lattice-work, one on either side of the proscenium front. This was probably the method adopted in ordinary drama and was seen as far back as 1513, when Bibbiena's epoch-marking (because mode-setting) comedy, La Calandra, first saw the light at Urbino. In the second method, which in all likelihood was the method followed in private operatic performances, elevated scaffolds for the musicians were ranged behind the side-scenes on both sides and extended from the front wings to the back wall. These scaffolds were made as high as possible so that room might be provided for passing beneath them. Care had to be taken that none of their supports rested on or even touched the stage, otherwise the bounding of the dancers would 
have seriously discomposed the organ-players and others. The supporting beams had the floor of the hall for base and passed through large roomy holes cut in the stage. If this was the alternative, can we wonder that the promoters of the first Venetian Opera-houses preferred the principle of the orchestra?

The negative evidence of Nicola Sabbatini is confirmed by the significant silence of Joseff Furtenbach. By elucidated picture and diagram given in his Newes Itinerarium Italiae, published at $\mathrm{Ulm}$ in 1627, and in his Architectura Recreationis, which appeared at Augsburg in 1640, Furtenbach reveals the mysteries of Italian stage building and scene-shifting but affords no clue to his acquaintanceship with an orchestra. Clearly the principle, even if formulated, had no vogue before the rise of Venetian Opera. The earliest pictorial evidence I know of testifying to the existence of the orchestra is a plate showing a ballet-scene in the opera of $L$ 'Hipermestra as given by the prince cardinal of Tuscany, in 1658, at the new Pergola Theatre, Florence, in honor of the Prince of Spain's birthday. ${ }^{1}$ It depicts a small, highly ornate coffer-like enclosure, occupying in length about a third of the width of the proscenium opening. Curiously enough, it is in 1658 also that the first trace occurs of the use of the term orchestra in its modern sense, and that, too, in England where the principle had not yet been established. Defining orchester in his Nero World of Words, Edward Phillips, Milton's nephew, begins by giving its ancient meanings and then adds, "it is also sometimes taken for the place where the musicians sit." It is noteworthy that in the seventh edition of the lexicon, issued in 1720 under the supervision of another hand, the latter clause is altered to "it is now taken for the Musick Gallery-or Place where the Musicians sit." This would lead one to believe that familiarity with the term had led to its general application, but, as a matter of fact, one cannot trace any employment of the term in England much before 1720, the good old Elizabethan designation of "music-room" having come to be applied to the musicians' new habitat. Thus, on June 2, 1716, the managers of Drury Lane notified one of their employes, "Mr. Castelman,-You are to let Mr. Devan, Mr. Latour, the Hoboy and Mr. Pots know that after Saturday, the 9th instant, the company have no further occasion for their performance in the music-room." In the Dublin theatre the term "music-room" survived to the middle of the eighteenth century.

'Reproduced from the opera-book in the second seriea of my The Elirabethan Playhouse and othor Studies (1913). 


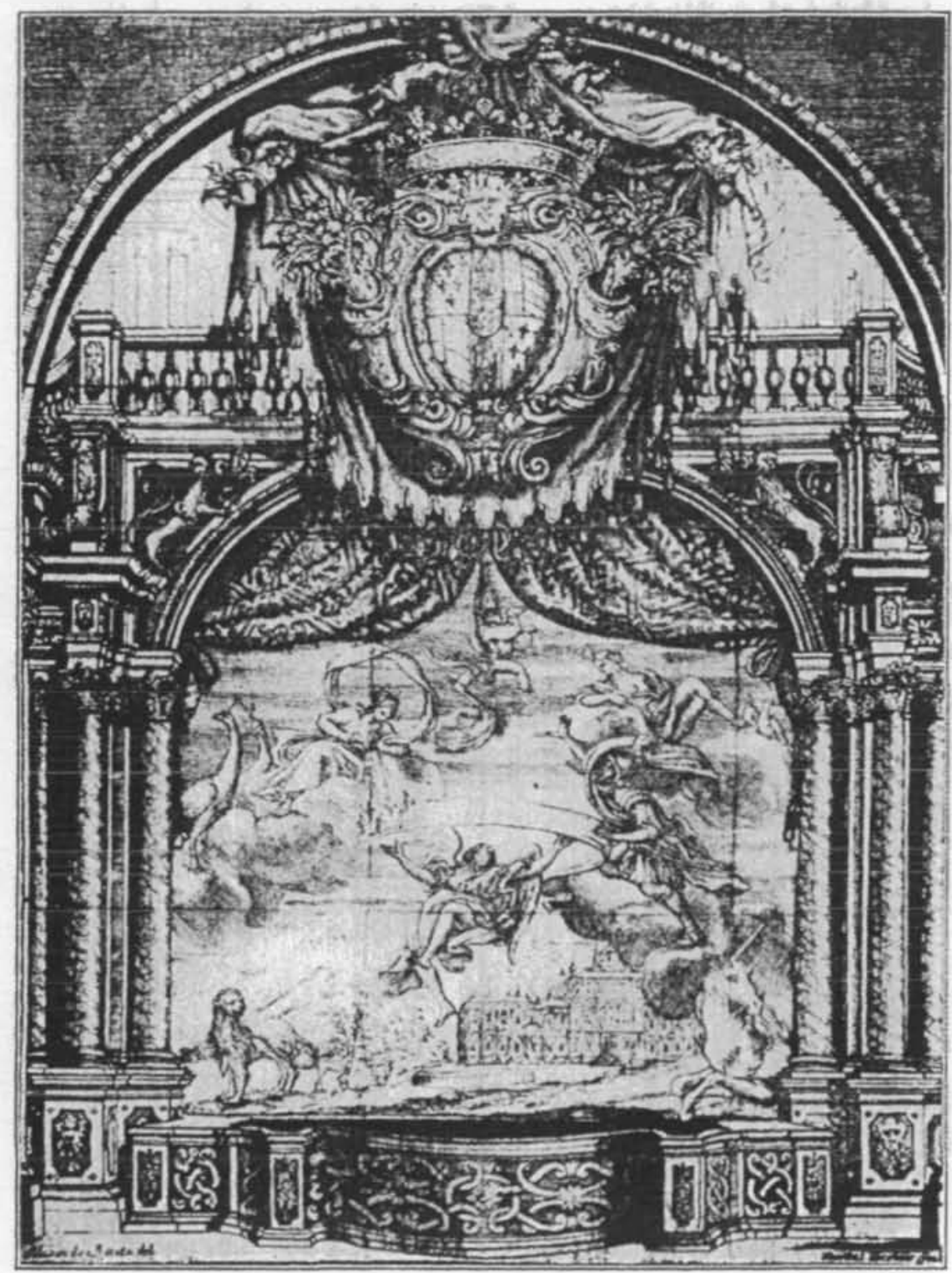

Proscenium, emblematic curtain, and orchestra of the new, small Ducal Theatre of Parma, 1690.

(Frontiopiece to "L'Ides di Tutto le Perfesioni.") 


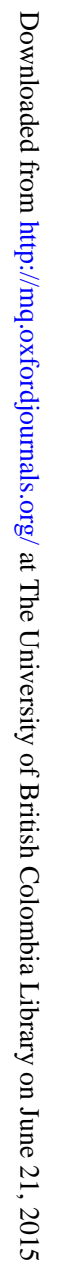


So much by way of necessary exordium. Turning now to my main theme, $I$ find myself absolved from entering upon any very elaborate discussion of the characteristics of Elizabethan stage music by the fact that the English theatre orchestra dates from Restoration times. Since, however, there was some carrying over of old musical conventions well into the first orchestral period, modifying the full force of the new principles and rendering the transition practically insensible, it is essential that some details should be presented of the scheme of theatrical music earlier in the century.

One has nothing but admiration for the artistry displayed by the wise Elizabethans in ulitizing music to assist illusion and heighten the emotional content of a scene. Music, for the most part, was treated by them as a thing of reverence and of mystery, a spiritual enjoyment whose source was to be obscured. Except when they occasionally appeared on the stage for purposes of high realism, the musicians were never seen at work. Their normal position was behind a curtain in an elevated bor in the tiring-house front, that permanent architectural background which formed an unvarying characteristic of the unenclosed platform stage. Just as "the music-room" differed from the orchestra in being within stage territory and in its capability of being used on occasion for purposes of dramatic action, so, too, the status and occupation of the Elizabethan stage musician had nothing in common with the specialism of the theatre musician of later times. This was largely due to the circumstance that from a remote period in the history of the English drama the identity of player and musician was largely confused. In early dramas, like Wilson's The Cobbler's Prophosic, the actor-singer frequently played his own accompaniments. In 1586 the English players, who were so much run after on the continent, not only enjoyed high reputation as musicians but were marvelled over as acrobats as well. Clearly the age of specialism was not yet. Like the Elizabethan super, the Elizabethan fiddler was "a hireling," with daily wages, and when not actively engaged in his own work was expected to do a super's, and go on with the crowds. As a rule, songs were sung in the music-room behind the shelter of the curtain, but when, for purposes of realism, in serenades, etc., they were given on the stage, he had to go on to accompany and sometimes say a few words in character. ${ }^{1}$ Unless actors

IIllusion was never outraged on the Blisabethen otage in the ruthless manner often practised on the modern otage, as, for example, in a drawing-room ecene where the singer comes down unblushingly to the footlight and is accompanied by the band. In Shakespeare's day a song sung on the stage and accompanied in the music-room would have been an impossibility. 
turned musicians oftener than musicians turned actors he was, in sooth, expected to have many accomplishments. In Timon of Athons we find the dancers following Italian precedent and providing their own music. In Monsiour Thomas a fiddler takes part in the dialogue and sings and plays.

Apart from the glamour and mystery with which they enshrouded their music (thus inspiring Shakespeare to fill Prospero's enchanted isle with supernatural strains), the Elizabethans deftly initiated and discreetly employed a principle afterwards to undergo excessive development in the molodrame. As in the opening of Troelfth Night, the lyric ecstasy of a speech was often accentuated by a running musical accompaniment. Death scenes and other pathetic episodes were similarly stressed. We shall see later how far the carrying over of these conventions affected the employment of the orchestra.

Since the principle of movable scenery operating behind an elaborately decorated proscenium arch was first brought to England from Italy by Inigo Jones and used by him as a setting for the Jacobean court masques, it might be thought that he also introduced the orchestra, transferring the idea, say, to the graceful court fantasies of the Caroline period. But this would be mere delusion. Even if the orchestra were in full-blown existence in Italy in Jones's later day, its adoption in the masques was precluded by the fact that its position was permanently occupied by a set of imposing proscenium steps down which the masquers descended from the stage to tread the mares of the dance on the floor of the hall. Inigo Jones has himself stilled all our doubts on this point by leaving us a design for a court stage and auditorium, now preserved among the Lansdowne Mss. in the British Museum, 1 in which the position of the musicians is clearly indicated. They occupied a box on either side of the proscenium front, a system, as already pointed out, long followed in Italy.

Baffled in our expectations of Inigo Jones, and still pursuing our quest, we turn with eager curiosity to the Commonwealth period. At this curiously inopportune hour D'Avenant, after disarming suspicion by giving at Rutland House a dreary precursor of the modern "Concert with Readings," has made feeble attempt to reflect the dazzling radiance of Italian Opera. It is 1656; in Italy the orchestra is now well established; D'Avenant's stage is cramped, his hall small: surely necessity as well as precedent will demand the institution of the orchestra. But

'Reproduced in G. H. Copling' Murie in the Blicabethan Thertro. 
the unexpected happens. In a contemporary account of the "First Day's Entertainment," which consisted of a series of ponderous Socratic disputations intermingled with music and song, we read:

The Musick was above in a loover hole railed about and covered with sarcenetts to conceale them, before each spech was consort musick. ${ }^{1}$

According to the directions in the book of the entertainment both singers and instrumentalists remained hidden from sight during the concerts. Here the precedent of the Elizabethan music-room seems to have been followed, although (and, D'Avenant having lived for a time in France, it is requisite to point this out) there was a somewhat similar practice on the contemporary French stage, due to the civil and religious disabilities under which all who appeared on the public stage in Catholic countries suffered. In 1650, when the Andromede of Corneille was given at the Petit Bourbon, the songs were rendered by vocalists hidden in latticed stage boxes while the ordinary players were engaged in the traffic of the scene. Nothwithstanding, however, the squeamishness of D'Avenant's concert singers and players, the issue could not be shirked, so far as the vocalists were concerned, four months later when the innovative knight produced in the same hall The Siege of Rhodes, the first English opera. They had to sing their parts upon the stage. But all the available evidence tends to show that the musicians were stationed on this occasion behind the scenes. D'Avenant, in his address to the Reader, says

It has often been wisht that our Scenes. . . . . had not been confined to eleven foot in height, and about fifteen in depth, including the place of passage reserv'd for the musick.

That this passage could not have conducted to some enclosure at the front, above or below the proscenium arch, is shown by the recently discovered designs for the scenery, etc., and plans for the stage." Moreover, the possibilities of an orchestra bor having been provided are negatived by the fact that the parapet of the stage was only 2 feet 6 inches high.

Abandoning Rutland House because of its manifold inconveniences, D'Avenant renewed his experiments (for they were nothing better) at the old Cockpit Theatre in Drury Lane, where

18tate Papore, Dom. Bor. Intorrepnum, 1656, CXXVII, art. 108.

'Cf. The Burtington Magarine for Apri-May, 1914, Mr. W. G. Ketth's important articles on "The Defigns for the First Movable Scenery on the Englinh Public Stage." 
he opened in December, 1658, with his so-called opera, The Cruelty of the Spaniards in Peru. Once more dreading Puritan hostility, and desiring for the time being to lull suspicion, he was careful to avoid all semblance of dramatic form and steered clear of the quicksands of plot and dialogue. Arranged in six "entries" instead of acts, The Cruelty can only be described as a slowly developed panorama with illustrative songs and dances. We read in the book how, towards the close of the first entry, the Chief Priest of Peru (who was practically the lecturer to the pictures) waved "his verge towards the Room where the Musick are plac'd behind a Curtain," with the result that a song was sung. Which reminds us that when worthy Master Pepys went to the Clothworkers' Hall on June 28, 1660, to dine with the company and hear some good music he recorded

where among other things I was pleased that I could find out a man by his voice, whom I had never seen before to be one that sang behind the curtaine formerly at Sir W. Davenant's opera.

It only remains to add that Sir Francis Dralce, the interlinked production which followed The Cruelty at the Cockpit, was much less epical and non-dramatic in form and certainly presented some singing on the stage. But we have no reason to suppose that from first to last during these interesting experiments the musicians ever exposed themselves to the public gaze.

When the King came to his own again, acting was hurriedly renewed in the old deserted theatres under all the old principles. Pepys expresses his disgust at the ragged performance of $A l^{\prime}{ }_{8}$ Lost by Lust at the Red Bull in March 1661, adding

and with so much disorder, amongst others, in the musique room, the boy that was to sing a song, not singing it right, his master fell about his ears and beat him so, that it put the whole house in an uproar.

The time was ripe for change and dramatic methods were now about to be revolutionized by the emergence of a new type of theatre, whose main differentiation lay in the employment of movable scenery. Old conventions, however, die hard, and the Elizabethan music-loft, so far from disappearing with the open platform and the permanent architectural background of which it had formed a part, succeeded in establishing itself above the proscenium arch in the new type of house. How long in England it maintained its efficacy, in face of the introduction and gradual encroachments of the orchestra, it would be difficult to say; but 
in the Dublin theatre (where musical plays had no vogue before the days of The Beggar's Opera) it held its pride of place until the dawn of the eighteenth century.

Under the new conditions the music-loft was only utilized, it would appear, for the three selections given at intervals before the rising of the curtain, and for the entr'actes. In the performance of ordinary drama (as contrasted with plays of the musicospectacular order) all necessity for the provision of an orchestra, in the narrow sense of the term, was precluded by the obstinate persistence of most of the old Elizabethan musical conventions. We know positively, from textual indications, that when a song or dance was given in a normal play-and nearly every PostRestoration comedy ended in a general dance - the instrumentalists came on with punctilious realism to provide the music. Not only that, but the dramatist was expected to insert a few words accounting for their presence. Note how ingeniously Congreve brings in the musicians and leads up to the song in the second act of The Double Dealer. So, too, in Mrs. Behn's The Amorous Prince (1671) Cloris is unable to dance a jig to dissipate Frederick's sadness until she has first gone off to procure music. To-day we take all this for granted; mention of the word "jig" would be the cue for the orchestra to strike a long-drawn chord.

Leaving ordinary drama aside, there were, however, in Dryden's day, musical problems which neither Elizabethan convention nor music-loft could solve. True, after The Siege of Rhodes, the supply of legitimate opera was negligible, but there was an abundance of what old Roger North calls "semi-operas," plays presenting, apropos des bottes, pastoral dialogue in song, operatic scenes and clumsily intercalated masques, not to speak of sundry perversions of Shakespeare abounding in song and dance. Most of these excrescences, being purely theatrical and not episodes of contemporary realism, did not admit of the bringing on of the musicians during the action. For these, unless we can assume there was much playing behind the scenes, the constitution of an orchestra seems to have been imperative. But the curious thing is that, while that epoch-marking theatre, the Duke's in Lincoln's Inn Fields, opened in June, 1661, with The Siege of Rhodes and was known for some time distinctively as "the Opera," it is not in connection with this, the first of the picture-stage houses, that we have the earliest reference to the establishment of the orchestra. Pepys, our only authority on the point, is silent till he comes to deal with the opening of the second of the new houses, the Theatre Royal in Drury Lane. Going there, on May 8, 1663, 
the second day of performance, to see an old play, The Humorous Lioutonant, Pepys writes:

The house is made with extraordinary good contrivance, and yet hath some faults, as the narrowness of the passages in and out of the pitt and the distance from the stage to the bores, which I am confident cannot hear; but for all other things it is well, only above all, the musique being below, and most of it sounding under the very stage, there is no hearing of the bases at all, nor very well of the trebles, which sure must be mended.

Rightly or wrongly, the impression one gains here is that the writer was dealing with a rank innovation. And that might very well be, for Tom Killigrew, the patentee of the new house, had been a decade earlier British Resident at Venice, and, armed with the knowledge gained there, was anxious to improve theatrical music in England. To the amelioration which set in after the passage of a few years, and that despite the British predilection for simple ballad tunes, he largely contributed, though his more pretentious schemes were balked. Pepys, in recording a conversation he had with him on the subject in February, 1667, points out that, whereas at the dawn of the Restoration the band consisted of "only two or three fiddlers," now there were "nine or ten of the best." As a matter of fact, English theatre music at this period was superior to French. Chappuzeau, after enumerating the London playhouses in his Europe Vivante (1667), proceeds to make invidious comparisons, much to English advantage:

Il faut ajouter. . . . . que la musique y est excellente et les Ballets magnifiques; qu'elles n'ont pas moins de douze violins chacune pour les Preludes et pour les Entr'actes; . . . .

Poor France had only six! One hears much of French influence upon the Restoration theatre but France can hardly have brought about the establishment of the orchestra in England because in respect to adopting that institution she was, strange to say, considerably belated. True, the musicians had assumed their now familiar position at court performances as early as May, 1664, but, in spite of a dubious assertion of Chappuzeau's presently to be cited, one has no trace of a public orchestra in France until the opening of her first Opera-house in 1671. By the way, it is noteworthy that an important clause in the king's privilege to Perrin for the establishment of that house was instrumental in bringing about a vital change at Molière's theatre. This indemnified "tous les Gentilshommes, Damoiselles et autres personnes 
puissent chanter au dit Optra" from loss of any of their rights or privileges by so doing. The moral influence of this salutary provision is shown by the following entry in the famous unofficial register of La Grange made in April 1671:

Jusques icy les musiciens et musiciennes n'avoient point voulu paroitre en public; mais ils chantoient à la Comédie dans des loges grillese et treillisses, mais on surmonta tous ces obstacles, et avec quelque legère dispance, on trouva des personnes qui chantèrent sur le thêtre à visage descouvert, habillex comme les comédiens, etc.

But, if Chappuzeau is to be believed, the musicians of the house of Moliere, so far from immediately emulating the singers' example, preferred for some years to remain in obscurity. Writing, in 1674, in his Le Theatro francois (Bk. iii: Ch. lii), Chappuzeau says:

Ci-devant, on les placait ou derriedre le thettre, ou sur les ailes, ou dans un retranchement entre le theatre et le parterre, comme en une forme de parquet. Depuis peu, on les met dans une des loges du fond d'où ils font plus de bruit que de tout autre lieu où on les pourrait placer. 1

He goes on to say that it would be advisable for them to learn the last lines of the act by heart, so that they would be able to begin the symphony at once, without waiting for the cry of "Play l" which was so often heard. Chappuzeau's statement that the orchestra had already been experimented with has to be taken on trust, but, assuming its accuracy, the whole passage shows that the position of the musicians, so far from being due to exigencies, was matter of caprice. This indetermination is noteworthy since it was not without its analogy in the Restoration theatre, where we find a similar chopping and changing.

One swallow makes not a summer, and the superiority of the English theatre rests not alone on Chappuzeau's ipse dixit. Other travellers, notably Sorbières in 1664 and Count Magalotti in 1669, testify to the same effect. Magalotti writes:

Before the comedy begins, that the audience may not be tired with waiting, the most delightful symphonies are played; on which account many persons come early to enjoy this agreeable amusement.

Harking back to the opening of Killigrew's Theatre Royal in 1663 , one is apt to suspect, in spite of the inference most readily

'Of Colliex, Anrale of the 8taga, 1831, III. 448, note. 
deducible from Pepys' comment, that the Duke's, being distinctively the Opera-house, had already introduced the orchestra. But the sole existing reference to the accommodation provided for the musicians at the Lincoln's Inn Fields theatre seems only to indicate the provision of a music-loft. On November 7, 1667, Pepys repaired to the Duke's to see the Dryden-D'Avenant version of The Tempest (which we must be careful not to confound with Shadwell's later, and, musically speaking, more elaborate version) but, arriving late and finding the house crowded, was compelled willy-nilly, "to sit in the side balcone over against the musique room." This position overhung the stage and was most undesirable.

The puzzling point is that, although we have fairly sound evidence of the use of an orchestra at the new Theatre Royal on its opening, we have also fairly sound evidence that, almost nine years later, when the house was burnt down, a music-loft was one of its features. In a contemporary ballad, dealing with the event, we read:

\footnotetext{
But on a sudden a Fierce Fire 'gan rage, In several scenes, and overspread the stage. The 'Horrors,' waiting on the dismal sight,

In keeping with the fact that the fire started below in the store where Orange Moll kept her fruit, this florid account begins with the stage and gradually ascends to the roof, near where the music room was. This music room might possibly have been a later addition, due to plaints similar to Pepys' about the music sounding under the very stage. One reculls that when the Theatre Royal was closed for some months during the period of the Great Plague, or about a couple of years after it was built, considerable alteration was effected in and about the stage.

The curiously contradictory evidence in respect to the accommodation for the musicians at the various Restoration and PostRestoration theatres can only be reconciled by assuming the concurrent employment at one and the same house, for a considerable stretch of time, of both music loft and orchestra. This hardly sounds rational but I shall clearly demonstrate later on 
this dual provision in connection with one particular theatre and strive to develop a theory accounting for it.

Meanwhile let us consider an item of interesting evidence clearly demonstrating that in 1665 the two picture-stage theatres were making at least occasional use of the orchestra. It is to be found in the Lord Chamberlain's accounts and runs as follows:

1664-5 March 20.

A Warrant to make up habitts of several coloured silkes for four and twenty violins, twelve of them being for his Majesty's service in the theatre Royall, and the other twelve habitts for his Majesty's service in his Highness the Duke of York's theatre; and also four and twenty garlands of severall coloured flowers to each of them after the same manner as those that were delivered to Sir H. Herbert, Master of his Majesty's Revells. All these habitts and garlands to be delivered to Mr. Killigrew for his Majesty's extraordinary service.

A like warrant of March 18 for habitts for the 24 violins, like Indian gowns but not so full, with short sleeves to the elboes, trymmed with tinsell about the neck and bottom and at the sleeves.

The Rev. H. C. de Lafontaine, from whose useful compilation, The King's Murick, the above extracts are taken, fails to see (p. 482) that the two items are not really associated. The warrant of March 18 clearly refers to provision for the new court theatre at Whitehall, which, according to Pepys, was opened on April 20 following. But taken together, the two entries admit of the interesting deduction that the King's band of 24 violins also constituted the bands at the two public theatres, twelve playing at each house. One must bear in mind that, whereas at these acting took place in the afternoon, court performances were invariably given at night. It is not on the whole surprising to find the King permitting his musicians to earn a little extra money by playing at the ordinary theatres, which, though public, were really royal appanages and depending for their patronage mostly on the courtiers. This was no more incongruous than his allowing the choristers of the Chapel Royal to sing in Shadwell's version of The Tempest at the Duke's in 1674. Surmise becomes certainty when at a later period we find positive evidence of the royal musicians playing at Drury Lane. In May, 1677, John Singleton, Theophilus Fitz, Henry Brockwell, Edmund Flower and Joseph Fashion, members of the King's band, petitioned the Lord Chamberlain against Charles Killigrew, Master of the Revels, "for dismissing their attendance at the playhouse."

Jumbling the two entries unwarrantably together, Mr. de Lafontaine arrives at the conclusion that the habits referred to 
in the warrant of March 20,1665, were supplied for the production at Drury Lane of The Indian Queen in January, 1664, an unjustifiable harking back, more particularly as the habits were specifically provided for use at both theatres. That the Indian gowns of the earlier warrant were kept for the court and formed the conventional attire there of the royal musicians is shown by orders of January 18, 1668-9 and February 17, 1673-4, in which they recur. North points out in his Momoires of Musick that from the time of James I the court musicians performing in masques had been attired in rich liveries "of divers coloured silk mantles and scarfs with rich capps, and the master in the shape of an Apollo." Whence was derived the convention of the Indian gowns may be divined by examining Van Lochum's engraving of a French court performance in 1635 , wherein the musicians, seated in a balcony close to the stage, are depicted wearing fancy gowns and feathered Indian head-dresses. ${ }^{1}$

Since it was not the business of Charles II to supply attire for the ordinary theatre musicians, one can only surmise that the habits provided for the twelve violins at either house were for special use on those accasions when the King visited the playhouse in state. And, since in an elevated proscenium music-room adorned with curtains, rich garb would have been wasted, it may also be surmised that the dresses were intended for use in an orchestra and possibly on the stage. Owing to their being set off with wreaths and other head-dresses on these gala nights, the musicians fell into the habit of wearing their hats on ordinary occasions, with the result that in 1699 some high and mighty folk, chafing that anything should come between the wind and their nobility, complained to the Lord Chamberlain of the playhouse fiddlers remaining uncovered in their august presence and got the terrible grievance redressed. Surely a hint to the managers would have sufficed.

We come now by chronological progression to the vital evidence testifying to the concurrent employment in the one theatre of both music loft and orchestra. In October, 1673, or almost two years after the opening of the imposing new Duke's Theatre in Dorset Garden, there was published as having been acted there, a piece of sensational fustian, by Elkanah Settle, called The Empress of Morocco. Notable among the several curious illustrations in the book is a view, now reproduced, showing the front of the stage with the play in action, and especially 


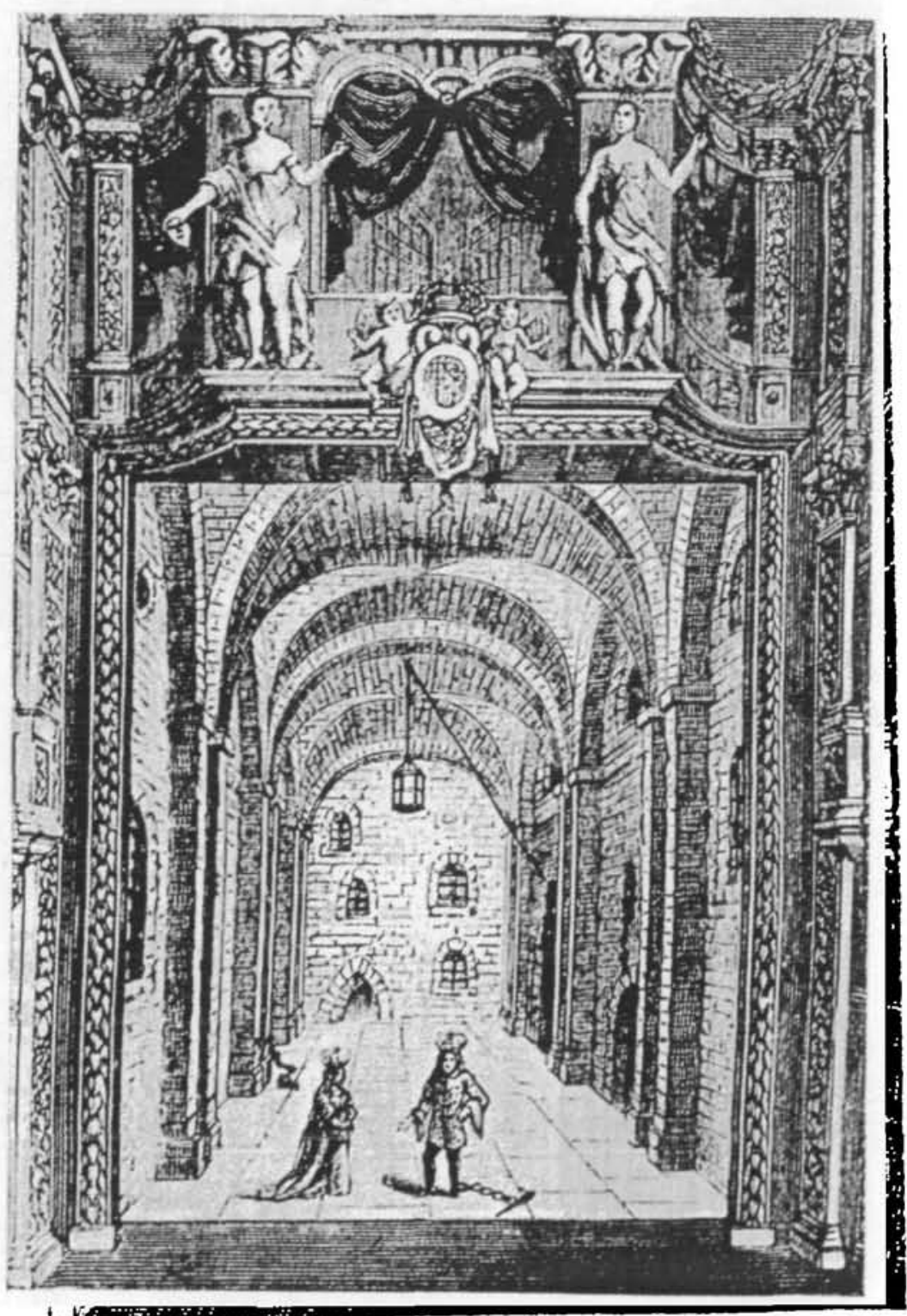

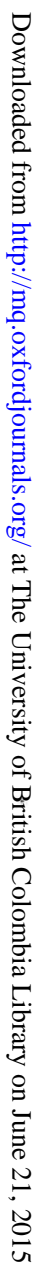

View of the stage front of the Duke's Theatre, Dorset Garden, 1678. Showing the musio-loft (from Settle's "The Empress of Morocco"). 


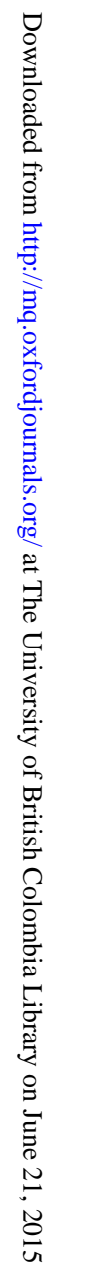


valuable as documentary evidence from the fact that it proves the existence of the music loft. Projecting over the proscenium, on a sort of shelf-like bracket, is to be observed a commodious room with three curtained openings, the front being adorned with statues of Tragedy and Comedy, the Duke of York's arms and a variety of musical emblems. Here the musicians played intermittently during the assembling of the audience and in the interacts. But within six months of the publication of Settle's play we have evidence at the same house of the employment of an orchestra. Shadwell's semi-operatic version of Dryden's Tempest was produced there in April, 1674, and published anonymously in the same year. At the opening of the play we read:

The front of the atage is opened and the Band of 24 violing with the Harpsicals and Theorbos, which accompany the voices, are placed between the Pit and the stage. While the Overture is playing the Curtain rises, and discovers a new Frontispiece, joyn'd to the great Pylasters, on each side of the stage.

It is apparent from this that the Duke's at this period boasted no permanent orchestral enclosure, the musicians only being placed in situ when elaborate musical productions demanded. Had the orchestra been a normal institution the opening sentence would have been superfluous. It would therefore appear that in 1674 there were two methods of accommodating the musicians in front, according to the nature of the piece presented. When ordinary plays were given, the regular band of twelve violins would officiate in the music-loft during the waits and probably appear on the stage, in accordance with time-honored convention, when the situation called for it. But when pieces of an operatic nature were performed, the band would be augmented and perforce would have had to resort to the orchestra. Probably for long the orchestra proved an eyesore to the pit, on whose demesnes it poached, a necessary evil of occasional obtrusion, tolerated on sufferance; and probably thence originated that tradition of hostility toward the fiddlers whose latent fires burst ever and anon into flame throughout the eighteenth century, not only in England and Ireland but in America.

It is important for us to note that we have clear evidence in connection with the performance of Shadwell's Tempest of the use of both music-loft and orchestra. The passage already cited from the play shows that the musicians only took their place in the orchestra shortly before the overture, or curtain tune, was to be given. But among the instrumental numbers written by 
Matthew Lock for the production and published by him in 1675 , we find the following:

First Music:-Introduction, Second Galliard, gavot.

Second Music:-Saraband, Lilk.

Curtain Tune.

Four Act-tunes:-Rustic air, Minuet, Corant, Martial Jig.

Conclusion: Canon 4 in 2 .

On this showing the First and Second Music (following the regular custom) must have been played in the music-loft. Where the entr'actes were given must remain an open question; but my own opinion is that, once in the orchestra, the musicians would have remained there.

Having the advantage in the beginning of being a permanent architectural feature of the house, the music-loft was difficult to oust. One sees the influence of its privacy in the conditions under which, in 1672, John Banister established the first English concerts; according to Roger North he "procured a large room in Whitefriars, near the Temple back-gate, and made a large raised box for the musicians whose modesty required curtains." The entertainment began at four o'clock in the afternoon, and the room was provided with small tables for drinking purposes. The charge was a shilling and one called for what one pleased.

As for the precise period when the English theatre orchestra became a permanent institution and entirely superseded the musicloft, that is difficult to determine. Evidence is scanty and conflicting. One asks one's self, for example, whether the dual system of accommodating the musicians was employed at the second Theatre Royal, Drury Lane on its erection in 1674. The production there in French of Perrin's opera of Ariane early in April, that is to say, very shortly after the opening, slightly preceded (practically synchronized with) the production of Shadwell's Tompest at the rival house. It is difficult to imagine that the one had an orchestra and the other had not, but the evidence is to that effect. In the books of Arians, one in French and one in English, printed for use in the theatre, a frontispiece is given showing the front of the stage with the opening scene in action.' No orchestra is indicated. The stage projects in a semi-oval figure and its base is ornamented with musical emblems. The inference, possibly fallacious, is that the musicians played behind the scenes. But in a recently discovered sectional plan of Sir Christopher Wren's, which from its

'Reproduced by we in The Elisabethan Playhouse and other Studiee (Second series), p. 140. 


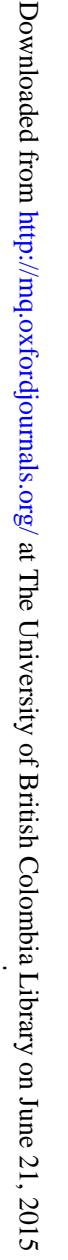




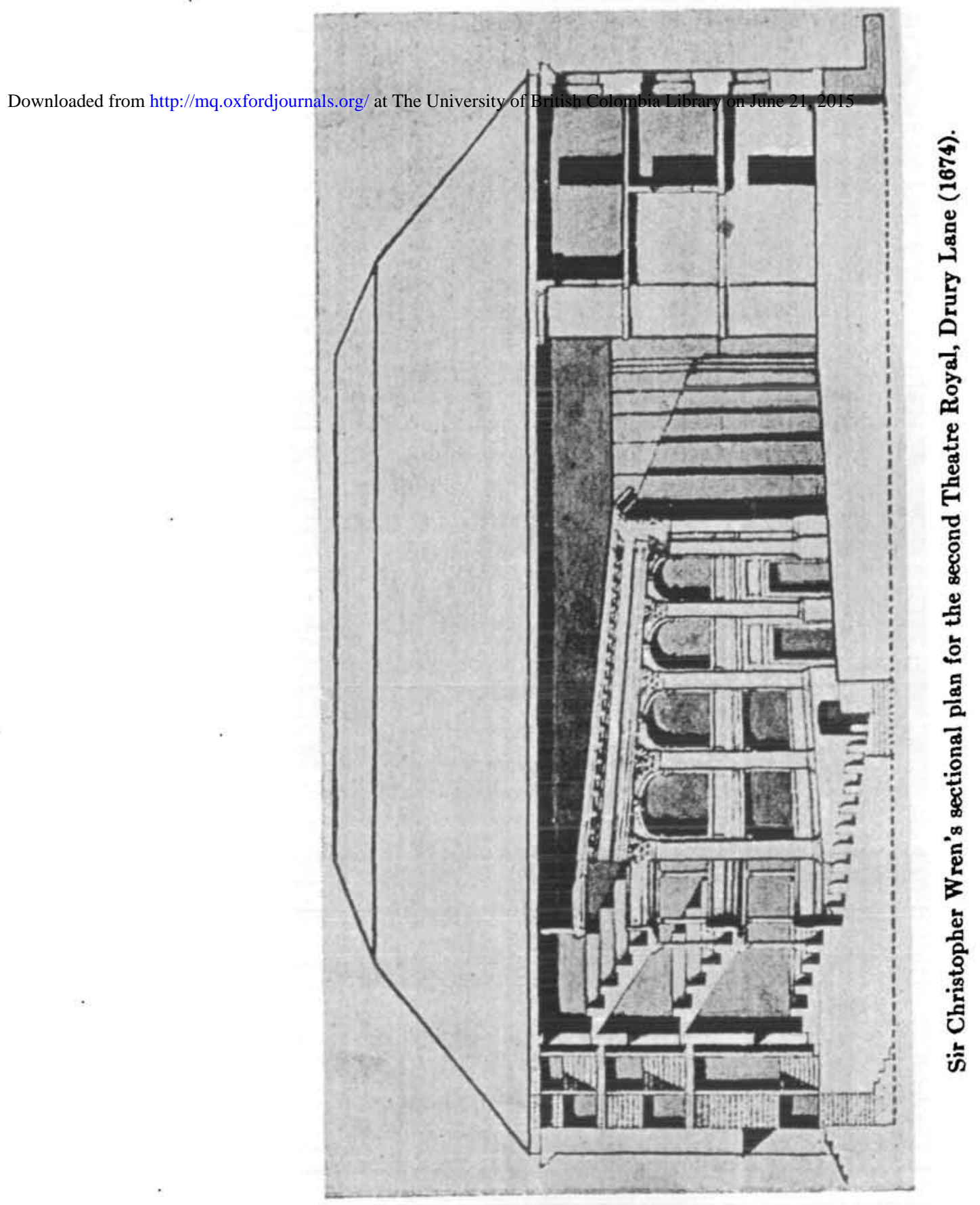


measurements seems to have been made for the second Theatre Royal, a house he is known to have designed, a permanent orchestral enclosure is clearly indicated. (See reproduction.)

Abandoning this apparently insoluble problem, my own opinion is that the supersession of the music-loft came eventually through that familiarization with the orchestra due to the great outburst of "dramatick opera" in the last decade of the century, beginning with Dioclesian, or the Prophetess, in 1690, and proceeding with King Arthur (1691), The Fairy Queen (1692) and divers other productions down to Purcell's swan-song, Bonduca, in 1695.

In the passage already cited from Shadwell's Tempest one has the first record of the employment of the harpsichord in an English orchestra. In its presence we have the belated batonwielding conductor foreshadowed, for, maintaining its pride of place for over a century, it was the tempo-giving instrument at which the leader long presided. Although in 1674 the orchestra was nothing better than a temporary expedient, its artistic influence had already begun to be felt. One notes the dawning of a certain musical relevancy. Superficialists will tell you with unblushing effrontery that the appropriate, as opposed to the conventional, overture dates from Gluck, oblivious of the fact that Matthew Lock's overture to Shadwell's Tempest deftly prepared the listener by its turbulency for the opening scene of the angry sea. Very soon this inducing of a mood preparatory to the rising of the curtain became to some extent a practice in connection with the preludes and act-tunes which Purcell and others regularly composed for the embellishment of new plays. Thus after Act II in Dryden's tragedy of Aureng-Zebe, as given at the Theatre Royal in 1675, we read "Betwixt the Acts, a Warlike Tune is plaid, shooting off Guns, and shouts of Soldiers are heard, as in an Assault."

Viewing the tendency of the regular theatre orchestra to solidify and remain impervious to outer influences, it was a happy circumstance that in Post-Restoration times there was no specialization of function, that the same house gave tragedy, comedy or opera indifferently. Soundness of orchestral equipment in the eighteenth century was largely due to instrumental experimentation in the pseudo-operas of this epoch. For it must be remembered that although the variety of instruments used in the course of an ordinary Post-Restoration play was only limited by the precise supply of the hour, the normal band for preludes and entr'actes consisted wholly of strings. Yet the theatre, with its hautboys, recorders, flageolets, flutes doux, was well equipped with wood. Recall how Pepys, on February 27, 1668, after 
seeing Massinger's old play of The Virgin Martyr at the Theatre Royal wrote:

But that which did please me beyond anything in the whole world was the wind musique when the angel comes down, which is so sweet that it ravished me, and indeed, in a word, did wrap up my soul so that it made me really aick, just as I have formerly been when in love with my wife.

All the elements of a scientific orchestra lay ready to hand, awaiting the genius who should know how to combine them. Hence it was that the end-of-the-century rage for that hybrid entertainment called "Dramatick Opera" served two good purposes, first in firmly establishing the orchestra and secondly, through that establishment, affording opportunities for testing new instrumental combinations. With Purcell's success in these experiments orchestration began. Not but that the way had been paved for him by his predecessors, especially Lock and Grabut. His trumpet-song in Dioclesian, "Sound, Fame, thy brazen trumpet" had doubtless been suggested by the trumpet obbligato accompanying Fame's solo and chorus at the close of Albion and Albanius, as set by Grabut in 1685. One is assuming, of course, that in both cases a trumpet was really used, and not, as was the case in the early renderings of "The Trumpet Shall Sound" in The Messiah, a small alto sackbut. Be that as it may, the natural trumpet, much as it was employed behind the scenes, never became incorporated with the normal theatre orchestra. One finds vivid illustration of this in the old Covent Garden account books, as preserved among the Egerton Mss. in the British Museum. Thus on September 12, 1735, when Hamlet was played the expense of the orchestral music was $£ 3.11 .10$. but this item did not include the kettle-drums, ${ }^{1}$ trumpets and sidedrum used in the play, which formed a separate entry and cost 17s. In looking over these books, by the way, it is interesting to note the increasing expense, connoting increasing importance, of the orchestra. In 1757, when there was a band of 22 performers, the cost was £5. 4. 4. per night. In 1766 it had increased to £6. 10. 10. almost double the expense of thirty years previously.?

Although the eighteenth-century orchestra partition was provided with a bristling array of spikes to deter the riotous

'Kettle-drums were frat made use of in opera by Lully at the French court late in the seventeenth century. Their orchestral use was unknown in Englend in 1740 when Handel employed them in his Water Hurio.

The maximum expenditure on musicinn in the Engtish Thestre in 1001 was thirty ohilling a day. 


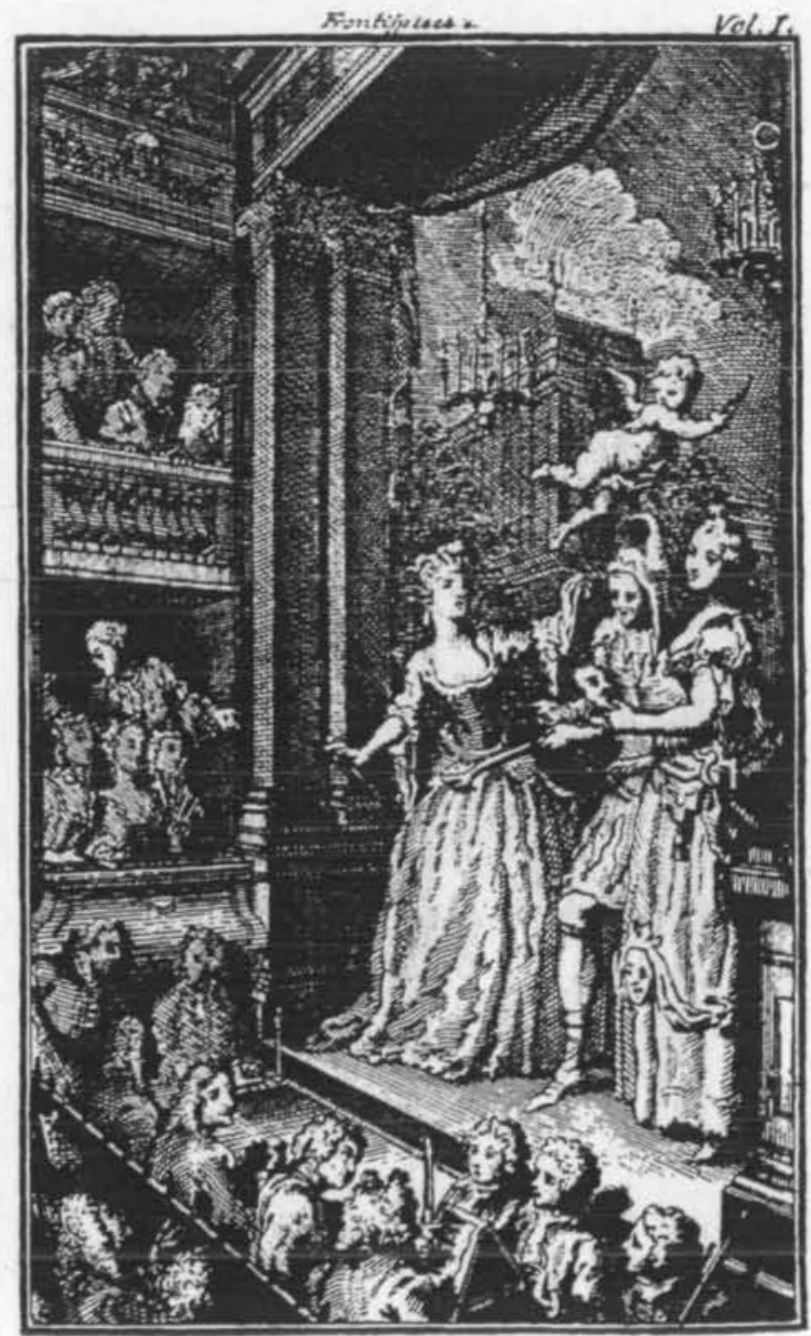

Emblematic frontispiece to "The Beauties of the English Stage" (London, 1737).

(Showing the orchestra of the period.) 


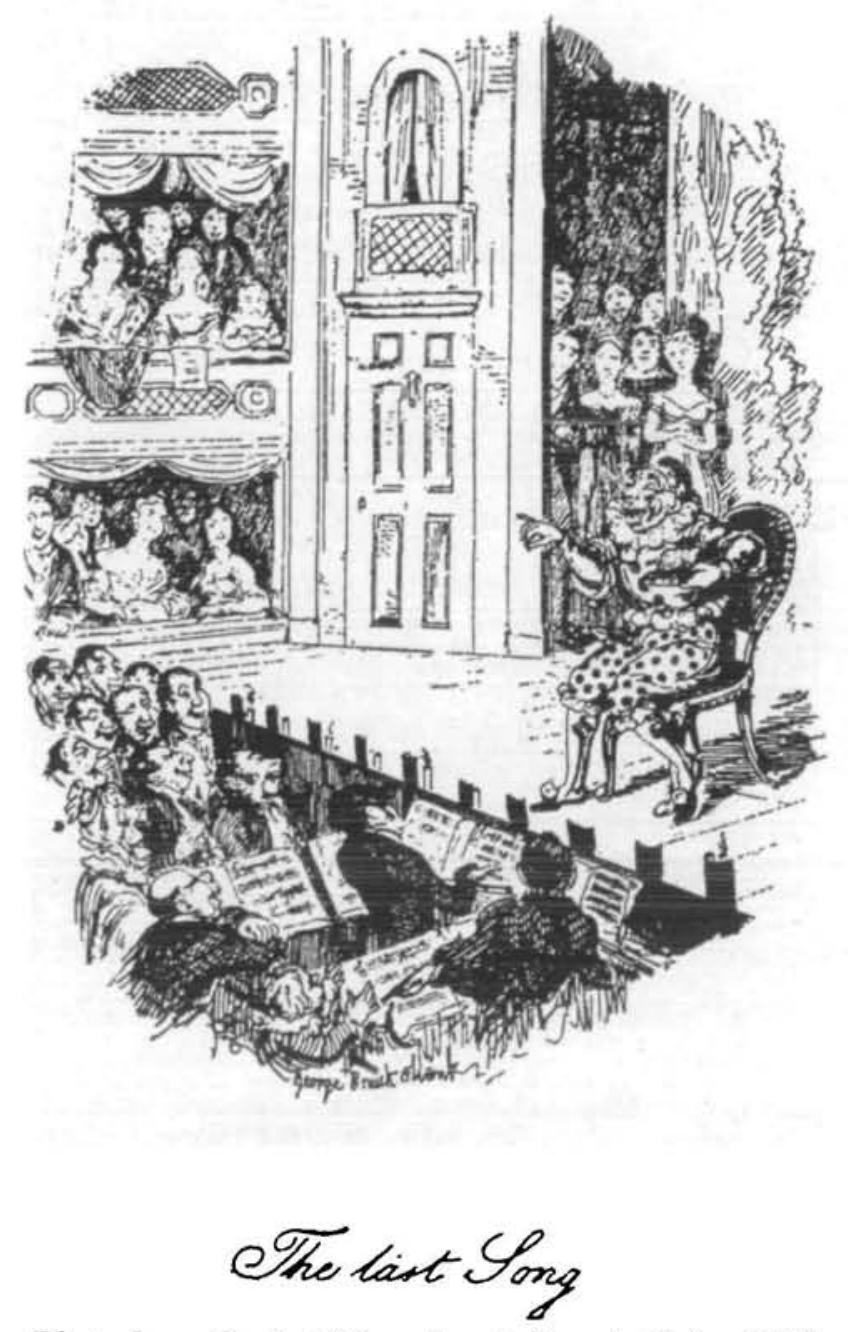

Plate from Boz's "Memoirs of Joseph Grimaldi." 
from climbing over on to the stage, it cannot be said to represent the line of demarcation between actors and audience. Owing to the importation of a curious French custom the musicians often found themselves incommoded by the presence of spectators. At the Theatre François from 1690 on ward the musicians occupied a small central enclosure in front of the stage, flanked on either side by benches for the accommodation of newsletter writers, dramatists free of the house and other privileged spectators. All the ground-floor space behind was devoted to the standing pit. Little by little these orchestral seats increased, pushing the pit into the background, until they finally developed into the familiar fautouils d'orchestre, otherwise stalls, of to-day. England, however, rejoiced in a seated pit, and when the primitive practice was introduced, it failed to produce analogous results. Whether or not Voltaire first brought it across the Channel, his is the name we first find associated with it. When the philosopher of Ferney came to London for the second time, in 1728 , he sedulously attended the theatres with the view of improving his knowledge of English. On such nights as he went to Drury Lane, Chetwood, the prompter, lent him the book of the play and ushered him to a seat in the orchestra. The result was that before six months had passed he both spoke and wrote very tolerable English.

The privilege of sitting in the orchestra was much esteemed by men of distinction, particularly those who, like Dr. Johnson, suffered from myopia, or, like Sir Joshua Reynolds, were hard of hearing. It is related of Garrick that on the premitre of the tragedy of Bragansa, at Drury Lane, in 1775, he sat among the musicians with a friend and that as the piece progressed his eyes became suffused with tears through the powerful acting of Mrs. Yates as the heroine. Forty years later Byron occupied a similar position on the night when Edmund Kean first played Othello in London, and, after Kean's magnificient outburst in the third act, he turned to Michael Kelly, the composer, and said, "Mr. Kelly, depend upon it, this is a man of genius." Not very long afterwards or, to speak by the card, in September, 1816, when the Drury Lane orchestral enclosure was considerably enlarged, a space was appropriated at either end for the use of spectators, and admission could be obtained there by paying box prices. In bygone days America had the misfortune to become infected with most of England's bad playgoing habits, and this was of the number. Spectators sat in the orchestra of the Park Theatre, New York, in 1822. 